\title{
Response of some chickpea (Cicer arietinum L.) genotypes to Orobanche foetida Poir. parasitism
}

\author{
Fatma Nefzi ${ }^{1}$, Imen Trabelsi ${ }^{1}$, Moez Amri ${ }^{2}$, Emna Triki ${ }^{1}$, Mohamed Kharrat ${ }^{1}$, \\ and Zouhaier Abbes ${ }^{1 *}$
}

\section{ABSTRACT}

In Tunisia, broomrape (Orobanche foetida Poir.) causes major drawbacks especially in faba bean (Vicia faba L.) Chickpea (Cicer arietinum L.) suffers little damage compared to faba bean, but with the winter sowing chickpea cultivars, broomrape might become a serious problem for chickpea cultivation. The development of resistant cultivars remains the most efficient way to solve this problem. The behavior of six chickpea genotypes to $O$. foetida was studied under field natural infestation and artificial inoculation in pots and petri dishes in greenhouse conditions. During the cropping seasons 2010-2011 and 2012-2013 the level of infection was very low. The number of emerged parasites per host plant varied from 0.18 to 0.43 and the incidence from $6.5 \%$ to $23 \%$. Among the six tested genotypes, G1, G2, and G4 showed partial resistance to $O$. foetida with low number and dry weight of emerged parasite and high grain yield compared to the other genotypes, although no significant differences were recorded. In pot experiments, the number and total dry weight of broomrape per plant were lower for G1 and G2 genotypes than the other genotypes. Parasitism does not affect significantly the shoot dry weight and number of pods of these genotypes. The total chlorophyll content was significantly reduced under infestation in all genotypes. In Petri dishes experiments, results showed that percent germination of $O$. foetida seeds varied from $49 \%$ to $65 \%$ and does not play a role in the resistance of chickpea genotypes. In contrast, broomrape attachment was lower and slower for the genotypes $\mathrm{G} 1, \mathrm{G} 2$, and G4 than the other genotypes. Resistance in chickpea genotypes was characterized by few parasite attachments on roots and a limited growth of established tubercles. No necrosis of attached tubercles was observed in the different experiments.

Key words: Broomrape, germination, resistance, tubercles.

${ }^{1}$ Carthage University, National Institute for Agricultural Research of Tunisia (INRAT), Hedi Karray street, 2080 Ariana, Tunisia. "Corresponding author (zouhaier.abbes@fst.rnu.tn).

${ }^{2}$ Carthage University, Regional Field Crop Research Center of Beja (CRRGC), Tunis street, km 5, 9000 Beja, Tunisia.

Received: 11 August 2015

Accepted: 9 December 2015.

doi:10.4067/S0718-58392016000200006

\section{INTRODUCTION}

Chickpea (Cicer arietinum L.) is one of the most popular grain legumes in many regions of the world. Its seed are important source of proteins to human nutrition. In Tunisia, the cultivated area and production have significant instability and decrease due to major biotic and abiotic constraints (Halila et al., 2010; Amri et al., 2014; Millán et al., 2015). The major pathogen affecting chickpea are Ascochyta rabiei, Fusarium oxysporum f. sp. ciceri, Rhizoctonia solani, Cuscuta spp. and also broomrapes (Mabrouk and Belhadj, 2012; Amri et al., 2014; Millán et al., 2015).

Chickpea is a host of crenate, fetid and Egyptian broomrapes (Orobanche crenata Forssk., O. foetida Poir., and Phelipanche aegyptiaca (Pers.) Pomel) that suffers little damage in the traditional spring sowing, but with the continuous spread of winter sowing, orobanche might become a problem in chickpea (Rubiales et al., 2003a). Among the latter broomrape species, $O$. crenata was reported as a major constraint for chickpea production in some Mediterranean countries (Garcia-Torres et al., 1991; Millán et al., 2015). Recently, high infestation level with $O$. crenata was reported in some winter chickpea fields in Morocco (Kharrat, personal communication). In Tunisia and especially in the Northern regions of the country, O. foetida is considered as a serious emerging problem but no important impact of $O$. crenata was reported. In these regions yield losses related to $O$. foetida infestation can reach more than $90 \%$ on faba bean (Abbes et al., 2007a). Orobanche foetida seems to be more pathogenic on faba bean than on other legume species (Abbes et al., 2008). Recently, Amri et al. (2009) demonstrated that $O$. foetida populations collected on chickpea plants were more aggressive and virulent on many legume host species than populations collected on other plant species such faba bean, pea, Calicotum spp., Scolymus spp., showing that even if chickpea does not suffer significant levels of infection, it contributes to the spread of an aggressive $O$. foetida population. According to Roman et al. (2007), the population of $O$. foetida present a high variability which could adapt very quickly to a new host.

Several strategies have been employed to control Orobanche spp. Chickpea infection seems to be controlled by varying the sowing date (Rubiales et al., 2003a) and by the use of some Rhizobium strains which induced a significant decrease in $O$. foetida seed germination and in the number of tubercles on chickpea roots (Hemissi et al., 2013). Chickpea is very sensitive to the standard glyphosate treatment recommended for orobanche control in faba bean, but shows good tolerance with imazethapyr 
treatment (Linke and Saxina, 1992; Garcia-Torres et al., 1999). Breeding for resistance is the most economic and environmentally friendly method of control. No complete resistance was identified and expression of resistance proved to be highly influenced by environmental conditions (Borg, 1986). Only recently, resistance has been reported in chickpea germplasm (Rubiales et al., 2003b). Linke et al. (1991) confirmed resistance of the chickpea line ILC 3279 in field and in plots trials. They found that this line had higher seed yield production and lower orobanche infestation than other tested genotypes.

Little information is available on response of chickpea to the fetid broomrape $O$. foetida. The objective of this study was to assess for the first time the resistance level of some chickpea genotypes to the parasitic species $O$. foetida, and to discern the mechanisms involved in this resistance. This was achieved through field trials and pot and petri dish experiments in greenhouse.

\section{MATERIALS AND METHODS}

\section{Plant material}

Six chickpea genotypes were used in this study, derived from crosses performed at International Center for Agricultural Research in the Dry Areas (ICARDA), two released cultivars ('Baja 1' and 'Nayer') and four advanced lines (Table 1). Orobanche foetida seeds were collected on faba bean plants during the cropping season 2011-2012 from the Beja region, Tunisia.

\section{Field experiment}

The six chickpea genotypes were grown, during the two cropping seasons 2010-2011 and 2012-2013, in a field naturally and homogeneously infested with $O$. foetida at the Oued-Beja research station $\left(36^{\circ} 43^{\prime} \mathrm{N}, 9^{\circ} 12^{\prime} \mathrm{E}\right)$ of Regional Field Crop Research Center of Beja (CRRGC), Tunisia. The trial was installed, during the last week of December each year, according a randomized complete block design with three replicates. The experimental unit consists of four rows of $4 \mathrm{~m}$ length $\left(8 \mathrm{~m}^{2}\right)$ and $0.5 \mathrm{~m}$ inter-row spacing. Each genotype was sown at seedling rate of 30 seeds $\mathrm{m}^{-2}$. No fertilizer or other chemical treatments were applied.

The field evaluation of orobanche infestation level was performed: (1) At pod setting and after orobanche emergence, three chickpea plants per plot were gently dug up from the soil. The total orobanche number per plant was recorded and scored visually using a 1 to 5 scale (1: attachment of haustorium to host root; 2: small tubercles without root development; 3: tubercles with crown roots without shoot formation; 4: underground tubercles with shoot formation; 5: emergence of spikes) (Labrousse et al., 2001). In addition, orobanche tubercle dry weights (DW) per plant was determined after drying fresh samples at $80{ }^{\circ} \mathrm{C}$ for 48 h. (2) At crop maturity, orobanche incidence (percentage of host plants showing emerged spikes using a 0 to $100 \%$ scale, Abbes et al., 2007a; 2007b), the number of emerged orobanche, total orobanche DW and grain yield were determined in the two central rows $\left(4 \mathrm{~m}^{2}\right)$. Additional traits as number of orobanche and orobanche DW per plant, chickpea 100-seed weight were also determined.

\section{Pot experiment}

Both chickpea and $O$. foetida seeds were surface-sterilized by soaking in calcium hypochlorite (1\%) for $15 \mathrm{~min}$ and were washed twice with sterilized water. The six chickpea genotypes were grown in $5 \mathrm{~L}$ pots containing sterilized soil and river sand (2:1) artificially inoculated with $20 \mathrm{mg}$

Table 1. Pedigree, origin and main characteristics of the studied chickpea genotypes.

\begin{tabular}{|c|c|c|}
\hline Genotype & Name/Pedigree & Main characteristics \\
\hline G1 & FLIP 98-22C & $\begin{array}{l}\text { - Tolerant to Ascochyta rabiei } \\
\text { - Resistant to race } 0 \text { of Foc* } \\
\text { - Recommended for winter sowing }\end{array}$ \\
\hline $\mathrm{G} 2$ & $\begin{array}{l}\text { 'Nayer' } \\
\text { (FLIP84-92C (X80TH176/ILC72xILC215)) }\end{array}$ & $\begin{array}{l}\text { - Small seed size (33-35 g per } 100 \text { seeds) } \\
\text { - Tolerant to A. rabiei } \\
\text { - Recommended for winter sowing } \\
\text { - Registered in the Tunisian catalogue in } 2003\end{array}$ \\
\hline G3 & $\begin{array}{l}\text { 'Beja 1' } \\
\text { (Amdoun1xILC3279)xILC200 }\end{array}$ & $\begin{array}{l}\text { - Small seed size ( } 34-37 \text { g per } 100 \text { seeds) } \\
\text { - Tolerant to A. rabiei } \\
\text { - Resistant to race } 0 \text { of Foc } \\
\text { - Recommended for winter sowing } \\
\text { - Registered in the Tunisian catalogue in } 2003\end{array}$ \\
\hline G4 & X96TH62-A4-A1-W1-A1-A1-A1-A1 & $\begin{array}{l}\text { - Tolerant to A. rabiei } \\
\text { - Resistant to race } 0 \text { of Foc } \\
\text { - Recommended for winter sowing }\end{array}$ \\
\hline G5 & X96TH86-W9-W1-A1-A1-A1-W1 & $\begin{array}{l}\text { - Tolerant to A. rabiei } \\
\text { - Resistant to race } 0 \text { of Foc } \\
\text { - Recommended for winter sowing }\end{array}$ \\
\hline G6 & X98-TH86-A4-A1-A1-A1-A1-A1 & $\begin{array}{l}\text { - Tolerant to A. rabiei } \\
\text { - Resistant to race } 0 \text { of Foc } \\
\text { - Recommended for winter sowing }\end{array}$ \\
\hline
\end{tabular}

"Resistant to fusarium wilt (Fusarium oxysporum f. sp. ciceris (Foc) race "0"). 
O. foetida seeds $\mathrm{kg}^{-1}$ substrate $(100 \mathrm{mg}$ O. foetida per pot). Five infested pots were prepared for each genotype. Two chickpea seeds per genotype were sown directly into each pot. Two weeks after chickpea emergence, seedlings were thinned to one plant per pot. Plants were grown in a greenhouse at $20 \pm 3{ }^{\circ} \mathrm{C}$, natural light and $70 \%$ relative humidity. Eighteen weeks after planting, at pods setting stage, the total number of tubercles per chickpea plant was counted and classified visually according to their developmental stage (Labrousse et al., 2001). In addition, orobanche DW $\left(80{ }^{\circ} \mathrm{C}\right.$ for $48 \mathrm{~h}$ ) per chickpea plant, pod number and shoot and root DW (g) of the different chickpea genotypes were recorded.

For the six studied genotypes, the content of the photosynthetic pigments chlorophyll a (chl a), chlorophyll b (chl b), and total chlorophyll (chl $\mathrm{t}=\mathrm{chl} \mathrm{a}+\mathrm{b}$ ) was determined, as described by Arnon (1949), on both infested and non-infested plants by $O$. foetida.

\section{Petri dish experiment}

Chickpea and orobanche seeds were surface sterilized as described above. Plastic petri dishes $(120 \times 120 \times 17 \mathrm{~mm}$, Greiner dishes, Sigma-Aldrich, St. Louis, Missouri, USA) are filled with sterilized sand moistened with $50 \mathrm{~mL}$ of water and then covered with a water-imbibed fiberglass filter paper. Three perforations were made in each petri dish: the big one was made in the highest board, to allow the shoot out of the dish, and the others were made on the opposite sides to allow root feeding in culture medium. Sterilized orobanche seeds (20 $\mathrm{mg}$ ) were spread between the dish cover and a fiberglass filter paper. Petri dishes were closed and vertically stored in a sterile polypropylene tray containing sterile distilled water. In the same time, chickpea seeds were pre-germinated (radicle of 4 to $5 \mathrm{~cm}$ length) and placed on the fiberglass filter paper in Petri dishes allowing a preconditioning step to orobanche seeds. This co-culture system was kept in the greenhouse at a temperature above $20 \pm 3{ }^{\circ} \mathrm{C}$, natural light and in humidity above $70 \%$. Dishes were covered with aluminum foil to exclude effect of light on roots. Total germination (\%) was calculated by using a binocular stereoscope. Four squares of $1 \mathrm{~cm}^{2}$ near infested faba bean roots per Petri dish were observed and the number of germinated seeds counted and expressed as percentage of total seeds. Estimated germination percent were performed weekly from 20 to $62 \mathrm{~d}$ after inoculation by $O$. foetida seeds (DAI). In addition, the total number of tubercles was counted every $3 \mathrm{~d}$ from 55 to $104 \mathrm{~d}$ after plant inoculation (DAI), and classified according to their developmental stage (Labrousse et al., 2001). Seven petri dishes were prepared for each genotype.

\section{Statistical analysis}

Results were analyzed using the SPSS 15.0 software (Windows edition, IBM, Armonk, New York, USA). Mean comparisons were made using Tukey test at $P=0.05$. The statistical model for pot and petri dish experiments involved a completely randomized design with five and seven replicates respectively, in which the host genotype was the unique fixed factor. For shoot DW, root DW, pod number and chlorophyll content, comparison includes the genotype with and without orobanche.

\section{RESULTS}

\section{Field experiment}

During the cropping season 2010-2011, significant differences in incidence were observed among the six studied genotypes. A highest incidence of $30 \%$ was recorded for the genotype G5 against a minima incidence of $2.67 \%$ and $3 \%$ recorded respectively for both genotypes G1 and G4. Nonsignificant differences were observed for grain yield and components (Table 2). In contrast, nonsignificant differences were observed for orobanche incidence parameter during the cropping season 2012-2013 (Table 2). Among the six tested genotypes the most important grain yield was recorded for both genotypes G2 and G4 with, respectively 8 and 9.2 g plant $^{-1}$, against a minimum of $3.13 \mathrm{~g} \mathrm{plant}^{-1}$ recorded for the genotype G5. By meaning the two cropping seasons 2010-2011 and 2012-2013, nonsignificant differences in incidence and grain yield were observed. A maximum orobanche incidence of $23.5 \%$ and $20.7 \%$ were observed respectively for the genotypes G3 and G5, which presented a respective grain yields of 8.56 and $5.88 \mathrm{~g} \mathrm{plant}^{-1}$. In contrast, incidence was lower especially for G4 that presented a grain yield of $10.22 \mathrm{~g} \mathrm{plant}^{-1}$. During the two cropping seasons, the average yield observed for the G2

Table 2. Estimated incidence, grain yield and one-hundred seeds weight for chickpea genotypes during the cropping seasons 20102011 and 2012-2013.

\begin{tabular}{|c|c|c|c|c|c|c|c|c|c|}
\hline \multirow[b]{2}{*}{ Genotypes } & \multicolumn{3}{|c|}{ Incidence } & \multicolumn{3}{|c|}{ Grain yield } & \multicolumn{3}{|c|}{100 seeds weight } \\
\hline & 2010-2011 & $2012-2013$ & Mean & $2010-2011$ & $2012-2013$ & Mean & $2010-2011$ & $2012-2013$ & Mean \\
\hline & \multicolumn{3}{|c|}{$-\%$} & \multicolumn{3}{|c|}{ g plant $^{-1}$} & \multicolumn{3}{|c|}{$-\mathrm{g}$} \\
\hline G1 & $2.67 \mathrm{a}$ & $11.00 \mathrm{a}$ & $6.83 \mathrm{a}$ & $12.07 \mathrm{a}$ & $5.04 \mathrm{ab}$ & $8.56 \mathrm{a}$ & $42.43 b$ & $41.00 \mathrm{a}$ & $41.72 \mathrm{ab}$ \\
\hline G2 & $18.33 \mathrm{ab}$ & $9.33 \mathrm{a}$ & $13.83 \mathrm{a}$ & $10.21 \mathrm{a}$ & $8.01 \mathrm{~b}$ & $9.11 \mathrm{a}$ & $36.83 \mathrm{a}$ & $35.66 \mathrm{a}$ & $36.25 \mathrm{a}$ \\
\hline G3 & $11.33 \mathrm{ab}$ & $35.67 \mathrm{a}$ & $23.50 \mathrm{a}$ & $12.37 \mathrm{a}$ & $7.65 \mathrm{ab}$ & $10.01 \mathrm{a}$ & $38.90 \mathrm{a}$ & $35.66 \mathrm{a}$ & $37.28 \mathrm{ab}$ \\
\hline G4 & $3.00 \mathrm{a}$ & $10.00 \mathrm{a}$ & $6.50 \mathrm{a}$ & $11.22 \mathrm{a}$ & $9.20 \mathrm{~b}$ & $10.22 \mathrm{a}$ & $46.40 \mathrm{~cd}$ & $42.33 \mathrm{a}$ & $44.37 \mathrm{~cd}$ \\
\hline G5 & $29.67 b$ & $11.66 \mathrm{a}$ & $20.67 \mathrm{a}$ & $8.62 \mathrm{a}$ & $3.13 \mathrm{a}$ & $5.88 \mathrm{a}$ & $47.90 \mathrm{~d}$ & $42.66 a$ & $45.28 \mathrm{~d}$ \\
\hline G6 & $20.67 \mathrm{ab}$ & $18.33 \mathrm{a}$ & $19.50 \mathrm{a}$ & $12.28 \mathrm{a}$ & $6.51 \mathrm{ab}$ & $9.39 a$ & $44.80 \mathrm{bc}$ & $37.00 \mathrm{a}$ & $40.90 b c$ \\
\hline
\end{tabular}

Values with the same letter per column are not significantly different according to Tukey test $(\mathrm{p}=0.05)$.

G1: FLIP 98-22C; G2: ‘Nayer’; G3: ‘Beja 1'; G4: X96TH62-A4-A1-W1-A1-A1-A1-A1; G5: X96TH86-W9-W1-A1-A1-A1-W1; G6: X98-TH86-A4-A1-A1A1-A1-A1. 
and G4 genotypes was higher than the one observed for the G5 (more than 1.5 and 1.7 times, respectively). Moreover, G4 and G5 genotypes produced heavy weight seeds compared to G2 genotype (Table 2).

During 2012-2013, all the studied genotypes showed a very few emerged $O$. foetida and thus a low total DW of emerged $O$. foetida per plant. Nevertheless, the number and total DW of attached $O$. foetida were higher in the G3, G5, and G6 genotypes compared to the genotypes G1, G2, and G4 (Table 3 ). The sampling performed at pod setting stage generated additional information related to orobanche infestation at the underground level for the six studied genotypes (Table 4). No significant differences were observed between the tested genotypes for total orobanche number per plant. Moreover, the proportion of parasite reaching the stage 5 at pod setting stage of the crop was higher on the G3, G5, and G6 genotypes (Table 4) than the other genotypes especially G2 and G4. No necrosis was observed on the attached parasites, regardless of the genotype.

\section{Pot experiment}

In pot experiment, despite the number of attached tubercles that was too-fold lower for the G2 and G4 genotypes than for G3 and G5 genotypes, nonsignificant difference was observed between the tested genotypes for orobanche number and DM per plant (Table 5). Most attachments were at subterranean stages, and the number of those reaching stage S5 was low

Table 3. Number and total dry weights (DW, g) of emerged Orobanche at crop maturity for chickpea genotypes during cropping season 2012-2013.

\begin{tabular}{lcc}
\hline Genotypes & $\begin{array}{c}\text { Orobanche number } \\
\text { per plant }\end{array}$ & $\begin{array}{c}\text { Orobanche DW per } \\
\text { plant }\end{array}$ \\
\hline G1 & $0.18 \mathrm{a}$ & $0.85 \mathrm{a}$ \\
$\mathrm{G} 2$ & $0.28 \mathrm{a}$ & $0.85 \mathrm{a}$ \\
$\mathrm{G} 3$ & $0.43 \mathrm{a}$ & $1.29 \mathrm{a}$ \\
$\mathrm{G} 4$ & $0.20 \mathrm{a}$ & $0.55 \mathrm{a}$ \\
$\mathrm{G} 5$ & $0.36 \mathrm{a}$ & $1.14 \mathrm{a}$ \\
$\mathrm{G} 6$ & $0.37 \mathrm{a}$ & $1.50 \mathrm{a}$ \\
\hline
\end{tabular}

Values with the same letter per column are not significantly different according to Tukey test $(\mathrm{p}=0.05)$.

G1: FLIP 98-22C; G2: 'Nayer'; G3: 'Beja 1'; G4: X96TH62-A4-A1-W1A1-A1-A1-A1; G5: X96TH86-W9-W1-A1-A1-A1-W1; G6: X98-TH86A4-A1-A1-A1-A1-A1.
Table 4. Total number and dry weight (DW) of Orobanche foetida collected at pod setting stage on different chickpea genotypes grown at Beja station during cropping season 20122013.

\begin{tabular}{lccccc}
\hline Genotypes & $\begin{array}{c}\text { Orobanche } \\
\text { number }\end{array}$ & $\begin{array}{c}\text { Orobanche } \\
\text { DW (g) }\end{array}$ & $\begin{array}{c}\text { Underground } \\
\text { tubercle } \\
\text { number }\end{array}$ & S5 & $\begin{array}{c}\% \text { of S5 } \\
\text { number }\end{array}$ \\
\hline G1 & $0.91 \mathrm{a}$ & $2.44 \mathrm{a}$ & $0.16 \mathrm{a}$ & $0.75 \mathrm{a}$ & 82.41 \\
$\mathrm{G} 2$ & $1.50 \mathrm{a}$ & $2.10 \mathrm{a}$ & $0.66 \mathrm{a}$ & $0.83 \mathrm{a}$ & 55.33 \\
$\mathrm{G} 3$ & $0.75 \mathrm{a}$ & $2.80 \mathrm{a}$ & $0.16 \mathrm{a}$ & $0.58 \mathrm{a}$ & 77.33 \\
$\mathrm{G} 4$ & $1.08 \mathrm{a}$ & $4.05 \mathrm{a}$ & $0.58 \mathrm{a}$ & $0.50 \mathrm{a}$ & 46.29 \\
$\mathrm{G} 5$ & $1.16 \mathrm{a}$ & $3.13 \mathrm{a}$ & $0.16 \mathrm{a}$ & $1.00 \mathrm{a}$ & 86.20 \\
$\mathrm{G} 6$ & $0.66 \mathrm{a}$ & $3.51 \mathrm{a}$ & $0.16 \mathrm{a}$ & $0.50 \mathrm{a}$ & 75.75 \\
\hline
\end{tabular}

Values with the same letter per column are not significantly different according to Tukey test $(\mathrm{p}=0.05, \mathrm{n}=9)$.

S5: emergence of spikes; G1: FLIP 98-22C; G2: 'Nayer'; G3: 'Beja 1'; G4: X96TH62-A4-A1-W1-A1-A1-A1-A1; G5: X96TH86-W9-W1-A1-A1A1-W1; G6: X98-TH86-A4-A1-A1-A1-A1-A1.

especially for the genotypes G2 and G6 (4.3\%, and 1.6\%, respectively).

Nonsignificant difference was observed between infested and non-infested plants for the root DW measurements in all genotypes (Table 6). On the other hand, shoot DW and number of pods of the G5 genotype were significantly reduced in infested plants compared to non-infested plants. For the other genotypes, nonsignificant reductions were observed. The chlorophyll content (Total chlorophyll content and chlorophyll a content) was significantly reduced under infestation in all genotypes (Figure $1 \mathrm{~A}$ and C). Nonsignificant reduction in chlorophyll b content was observed only in G2 (Figure 1B). In general, the Chlorophyll content reduction was more important in the G5, and G6 genotypes than the other genotypes especially G2. No tubercle necrosis was observed on all genotypes confirming thus the field results.

\section{Petri dish experiment}

Percentage germination of $O$. foetida seeds was recorded weekly in the vicinity of chickpea roots during $62 \mathrm{~d}$ after inoculation by $O$. foetida seeds (DAI) (Figure 2). The parasite seeds started to germinate $25 \mathrm{DAI}$, regardless of the host genotype. Our data suggested that percent germination rose gradually and generally was optimal 41 DAI near chickpea roots. At this date, percentage germination is high for all genotypes reaching 49\%-65\% without significant differences

Table 5. Total number and dry weight (DW) of Orobanche foetida collected on different chickpea genotypes grown in pot experiment.

\begin{tabular}{|c|c|c|c|c|c|c|c|c|}
\hline Genotypes & $\begin{array}{c}\text { Orobanche } \\
\text { number }\end{array}$ & $\begin{array}{l}\text { Orobanche } \\
\text { DW (g) }\end{array}$ & $\begin{array}{l}\text { Underground } \\
\text { tubercle number }\end{array}$ & $\mathrm{S} 2$ & S3 & S4 & S5 & $\%$ of S5 \\
\hline G1 & 1.28ab & $0.28 \mathrm{a}$ & $1.14 \mathrm{a}$ & $0.57 \mathrm{ab}$ & $0.42 \mathrm{a}$ & $0.14 \mathrm{a}$ & $0.14 \mathrm{a}$ & 10.93 \\
\hline G2 & $3.28 \mathrm{abc}$ & $0.40 \mathrm{a}$ & $3.14 \mathrm{a}$ & $0.85 \mathrm{abc}$ & $0.42 \mathrm{a}$ & $1.85 \mathrm{ab}$ & $0.14 \mathrm{a}$ & 4.27 \\
\hline G3 & $8.57 \mathrm{c}$ & $1.49 \mathrm{a}$ & $7.85 \mathrm{a}$ & $2.85 b c$ & $1.14 \mathrm{ab}$ & $3.85 \mathrm{~b}$ & $0.71 \mathrm{a}$ & 8.28 \\
\hline G4 & $3.71 \mathrm{abc}$ & $1.09 \mathrm{a}$ & $3.14 \mathrm{a}$ & $0.57 \mathrm{ab}$ & $0.71 \mathrm{ab}$ & $1.85 \mathrm{ab}$ & $0.57 \mathrm{a}$ & 15.36 \\
\hline G5 & $7.42 b c$ & $2.61 \mathrm{a}$ & $6.71 \mathrm{a}$ & $2.85 b c$ & $1.00 \mathrm{ab}$ & $2.85 \mathrm{ab}$ & $0.71 \mathrm{a}$ & 9.57 \\
\hline G6 & $8.85 \mathrm{c}$ & $0.42 \mathrm{a}$ & 8.71a & $3.28 \mathrm{c}$ & $1.71 b$ & $3.71 b$ & $0.14 \mathrm{a}$ & 1.58 \\
\hline
\end{tabular}

Values with the same letter per column are not significantly different according to Tukey test $(\mathrm{p}=0.05, \mathrm{n}=5)$.

S2: small tubercles without root development; S3: tubercles with crown roots without shoot formation; S4: underground tubercles with shoot formation; S5: emergence of spikes.

G1: FLIP 98-22C; G2: 'Nayer'; G3: 'Beja 1'; G4: X96TH62-A4-A1-W1-A1-A1-A1-A1; G5: X96TH86-W9-W1-A1-A1-A1-W1; G6: X98-TH86-A4-A1A1-A1-A1-A1. 
Table 6. Parasitism effect on pod number and shoot and root dry weight (DW) on different chickpea genotypes grown in pot experiment.

\begin{tabular}{|c|c|c|c|c|c|c|}
\hline \multirow[b]{2}{*}{ Genotypes } & \multicolumn{3}{|c|}{ Non infested plants } & \multicolumn{3}{|c|}{ Infested plants } \\
\hline & Shoot DW & Root DW & Pod number & Shoot DW & Root DW & Pod number \\
\hline & 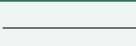 & 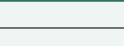 & & $\longrightarrow$ & 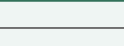 & \\
\hline G1 & $14.23 \mathrm{cdef}^{*}$ & $3.20 \mathrm{abc}$ & $23.00 \mathrm{ab}$ & $9.40 \mathrm{abc}$ & 3.09abc & 16.42ab \\
\hline G2 & $13.42 \mathrm{bcde}$ & $3.85 \mathrm{abc}$ & $22.14 \mathrm{ab}$ & 12.73abcde & 3.93abc & $19.85 \mathrm{ab}$ \\
\hline G3 & $16.56 \mathrm{ef}$ & $3.36 \mathrm{abc}$ & $24.42 \mathrm{ab}$ & 11.45abcde & $3.04 \mathrm{abc}$ & $23.14 \mathrm{ab}$ \\
\hline G4 & $15.25 \mathrm{def}$ & $5.00 \mathrm{c}$ & $21.85 \mathrm{ab}$ & 12.89abcde & 3.98abc & $18.85 \mathrm{ab}$ \\
\hline G5 & $19.42 \mathrm{f}$ & $4.35 b c$ & $27.71 b$ & $10.05 \mathrm{abcd}$ & $3.12 \mathrm{abc}$ & $14.42 \mathrm{a}$ \\
\hline G6 & $8.33 \mathrm{ab}$ & $2.77 a b$ & $18.42 \mathrm{ab}$ & $7.77 \mathrm{a}$ & $1.97 \mathrm{a}$ & $16.14 a b$ \\
\hline
\end{tabular}

Values with the same letter per column are not significantly different according to Tukey test $(\mathrm{p}=0.05, \mathrm{n}=5)$.

G1: FLIP 98-22C; G2: 'Nayer'; G3: 'Beja 1'; G4: X96TH62-A4-A1-W1-A1-A1-A1-A1; G5: X96TH86-W9-W1-A1-A1-A1-W1; G6: X98-TH86-A4-A1A1-A1-A1-A1.

Figure 1. Effect of Orobanche foetida on chlorophyll a (A), chlorophyll b (B) and total chlorophyll (chlorophyll $\mathbf{a}+\mathbf{b})(\mathrm{C})$ contents in different chickpea genotypes. Data are means $\pm \mathrm{SE}$ $(\mathbf{n}=3)$.
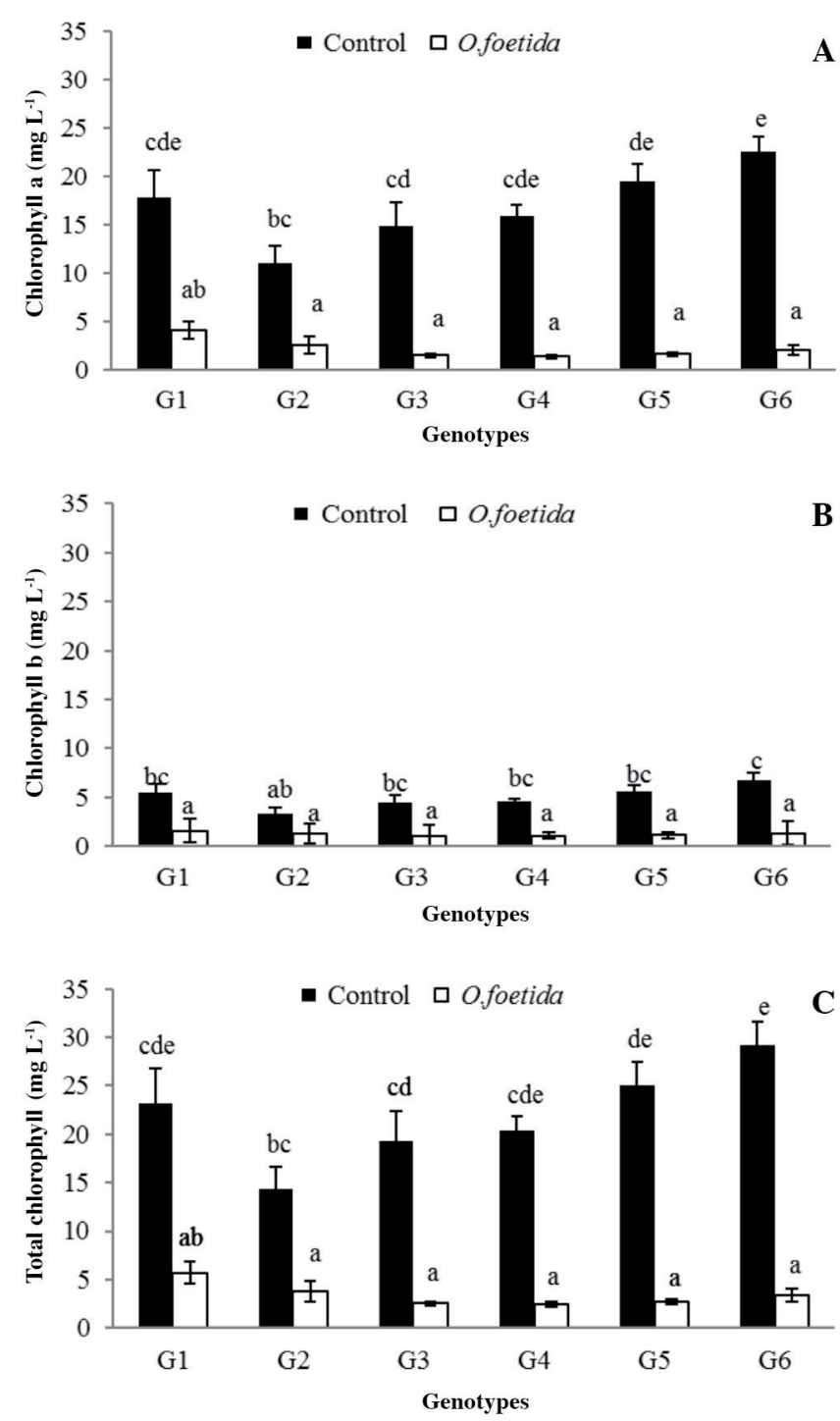

Control: non infested plants; G1: FLIP 98-22C; G2: 'Nayer'; G3: 'Beja 1'; G4: X96TH62-A4-A1-W1-A1-A1-A1-A1; G5: X96TH86-W9-W1-A1-A1A1-W1; G6: X98-TH86-A4-A1-A1-A1-A1-A1.
Figure 2. Germination rate of Orobanche foetida on different chickpea genotypes in vitro. Data are means $\pm \mathrm{SE}(n=7)$.

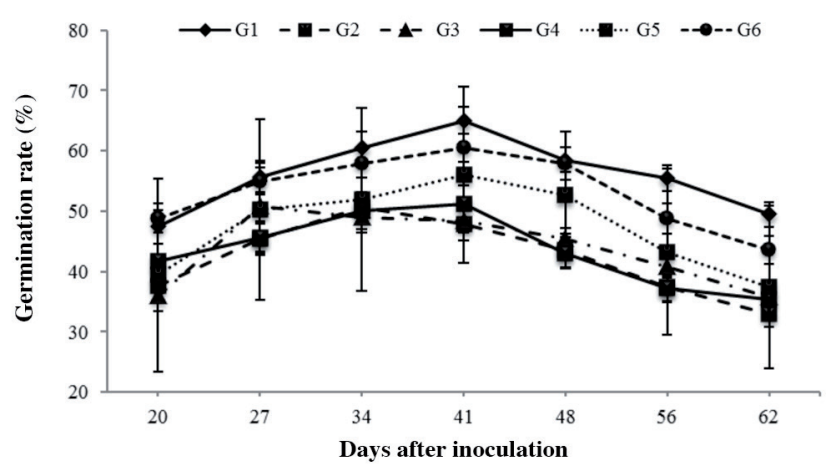

G1: FLIP 98-22C; G2: 'Nayer'; G3: 'Beja 1'; G4: X96TH62-A4-A1-W1A1-A1-A1-A1; G5: X96TH86-W9-W1-A1-A1-A1-W1; G6: X98-TH86A4-A1-A1-A1-A1-A1.

between genotypes. The lowest germination percentages were observed for genotypes G2, G4, and G6 compared to those recorded for the genotypes G1, G3, and G5. For all the chickpea genotypes, examination under binocular loupe showed radicle browning of some germinated orobanche seeds resulting thus in the death of the parasites. The percentage of browning germinated seeds was very low on all genotypes.

In petri dishes experiment, $O$. foetida attachments kinetics and development was recorded once every $3 \mathrm{~d}$ starting from day 55 until 104 DAI. Results showed that for all genotypes, the tubercle number increase gradually reaching a maximum of 4.14 tubercles on the G5 genotype. The first broomrape attachments appeared already 55 DAI for all chickpea genotypes except for the genotype $\mathrm{G} 2$ for which attachments were observed $3 \mathrm{~d}$ later (Figure 3). The roots of G3, G5, and G6 infested genotypes carried an average of four tubercles per host plant at 104 DAI against a low tubercle number of two tubercles recorded for the genotypes G2 and G4 (Figure 3). No parasite necrosis was observed before or after attachment to the roots of either genotype.

In addition, changes in the percentage of tubercles reaching stage 4 (S4) by the total number of fixed tubercles during the 104-d culture period were examined as an index of the growth of established tubercles. A significant difference was 
Figure 3. Total tubercles number on different chickpea genotypes in vitro. Data are means $\pm \mathrm{SE}(\mathrm{n}=7)$.

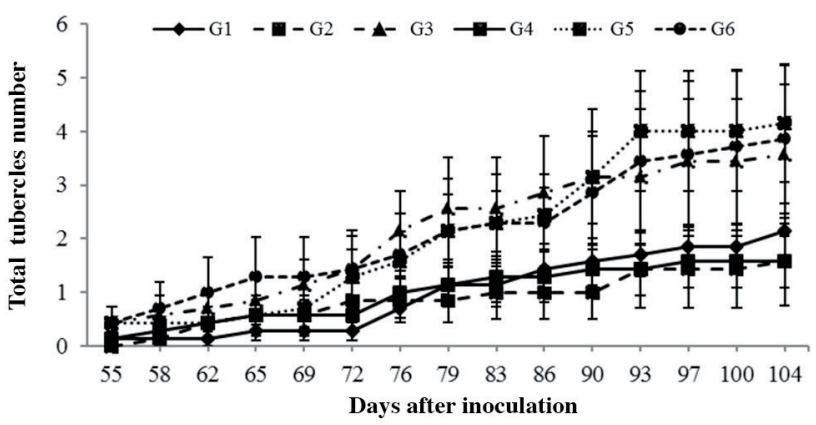

G1: FLIP 98-22C; G2: 'Nayer'; G3: 'Beja 1'; G4: X96TH62-A4-A1-W1A1-A1-A1-A1; G5: X96TH86-W9-W1-A1-A1-A1-W1; G6: X98-TH86A4-A1-A1-A1-A1-A1.

recorded among the studied genotypes for this percentage. Results showed that the percentage of tubercles reaching stage 4 (S4) increased from 76 DAI on G5 roots, to reach a high value at $104 \mathrm{DAI}$. By contrast, this percentage was much lower, especially on the G2 genotype with a slight increase recorded at 104 DAI. The G5 attached tubercles showed an important growth rate compared to the other genotypes especially G2. The speed of growth and development of the parasite once attached seems to be slowed down especially with the genotype G2 (Figure 4).

\section{DISCUSSION}

The aim of this work was to study for the first time the response of some chickpea genotypes to $O$. foetida under natural infestation in field and artificial infestation in pots and petri dishes in greenhouse conditions. In infested field, several criteria have been used by authors to quantify resistance to orobanche infestation (Rubiales et al., 2006; Abbes et al., 2007a). The best index is the number of orobanche shoots per host plant, which gives the most reliable estimation of the total infestation level (Rubiales et al., 2006). Other

Figure 4. Evolution of the percentage of tubercles reaching stage 4 (S4)/total number of tubercles in the different chickpea genotypes in vitro $(\mathrm{n}=7)$.

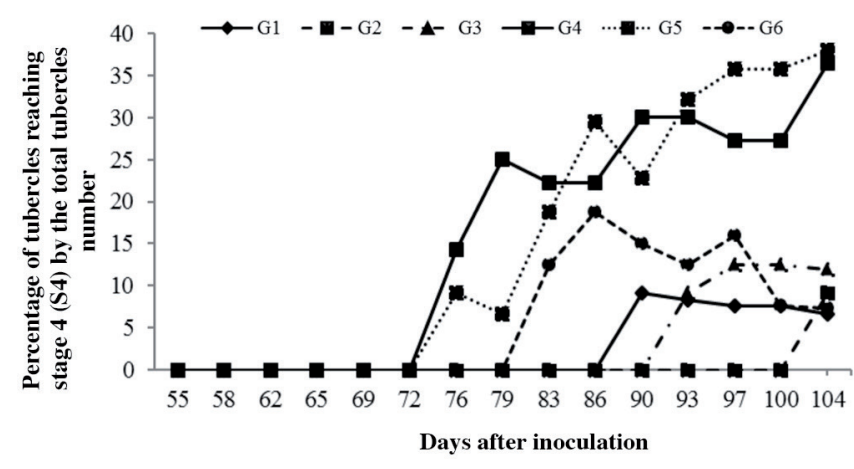

G1: FLIP 98-22C; G2: 'Nayer'; G3: 'Beja 1'; G4: X96TH62-A4-A1-W1A1-A1-A1-A1; G5: X96TH86-W9-W1-A1-A1-A1-W1; G6: X98-TH86A4-A1-A1-A1-A1-A1. indexes could be used as severity, incidence, and index of parasitism (Abbes et al., 2007a; 2011). The field evaluation performed during the two cropping seasons 2010-2011 and 2012-2013 showed a low infection level for the different studied genotypes with a maximum incidence of $23 \%$ and 0.43 parasite emerged shoot per host plant. Similar results were observed in Spain on some chickpea accessions with $O$. crenata where the infestation level reached a maximum of 50\% remaining low compared to faba bean (Rubiales et al., 2003a). In Egypt, Soliman et al. (2012) reported a higher parasitism incidence on chickpea with $O$. crenata. The level of infestation is related to host genotype, orobanche species and the environmental conditions. According to Amri et al. (2009), even if chickpea does not suffer significant infection levels, it contributes to the spread of most virulent and aggressive $O$. foetida populations compared to those collected on other host species. In Tunisia, the serious problem of $O$. foetida on chickpea should be taken into consideration and more attention could be provided to this pathosystem (chickpea-O. foetida) to control the spread of such virulent and aggressive $O$. foetida populations in order to minimize yield losses on faba bean, chickpea, or other host species.

In addition, under field conditions, nonsignificant differences between genotypes for the emerged tubercles number and DW and incidence level were observed. The number of emerged broomrape per host plant was not sufficient to separate the tolerant genotypes from the susceptible genotypes. Nevertheless, G1, G2, and G4 genotypes seem to be less susceptible compared to the other genotypes. The lowest number and DW of emerged parasites were observed on these genotypes.

The examination of the underground infestation by uprooting the host plant at pod setting stage and by counting the number of underground parasite attachments allowed us to confirm the behavior of each genotype. As observed for emerged parasites, nonsignificant differences were observed between genotypes for the total orobanche attachments (emerged and non-emerged shoots). At this crop development stage, the proportion of tubercles reaching the stage 5 was lower on both genotypes G2 and G4 than on the other genotypes, especially G5. No necrosis was observed on the attached parasites, regardless of the genotype. At crop maturity, the seed yield per host plant was higher in G2 and G4 genotypes than it was in the G5 genotype. The low infestation level and the nonsignificant differences observed under field conditions can be explained by the development of a deep root system that characterizes chickpea plants. More than $70 \%$ of the chickpea root system grows beyond a $20 \mathrm{~cm}$ depth where the broomrape infection occurs. Such root system development may also explain the low infection observed in chickpea compared to faba bean. In addition, the results showed that only genotypes G2 and G4 expressed partial resistance to $O$. foetida in comparison to G3 and G5 genotypes. These two genotypes were less susceptible and may carry some genes that could be involved in this partial resistance to $O$. foetida. The presence of resistance 
in chickpea to orobanche was described by several other studies (Rubiales et al., 2003b; Sillero et al., 2005).

In order to confirm the comparative susceptibility of the six genotypes to $O$. foetida, artificial infestation experiments were carried out in pots and petri dishes in a greenhouse. In pots experiment and among the six studied genotypes, G3, G5, and G6 were the most susceptible to $O$. foetida with a high broomrape number and DW. The most important infestation level was observed for the genotype G5, which presented the highest number of tubercles reaching the stage 5 against an important resistance/tolerance level observed for the genotype G2 (Table 5). For the six studied genotypes, no tubercle necrosis was observed confirming thus the field results. In this experiment, $O$. foetida parasitism caused a significant reduction of shoot DW and pod number per plant on the G5 genotype. A similar effect was observed on G3 genotype where the pod number per plant was reduced by $50 \%$ compared to the uninfected control (Table 6). Ter Borg et al. (1994) signaled that the tubercle number per plant is the major indicator of resistance to broomrape and that less is the number of orobanche on the host plant, higher is the average weight of the host plant biomass. The significant loss of the aerial part DM observed for the genotypes G3 and G5 could be related to the high number of attached orobanche tubercles including high number of parasites reaching the stage 5 . For the six evaluated genotypes, the decrease of host plant biomass and pod number per host plant due to the $O$. foetida parasitism effect was accompanied by a significant decrease of leaves chlorophyll content. Similar results were reported with the pathosystems faba bean $/ O$. foetida-O. crenata (Trabelsi et al., 2015) and tomato/P. ramosa (Mauromicale et al., 2008). These parasites caused significant reduction in the aboveground biomass of their hosts and leaves chlorophyll content resulting in an altered photosynthetic capacity in the host plant.

Petri dishes experiments were used to study the orobanche infection process and to better identify the behavior of the six chickpea tested genotypes under $O$. foetida parasitism. Results showed that the $O$. foetida seeds germination percentage was relatively high for all the studied genotypes (49\%-65\%). In this study we used $O$. foetida seeds collected on faba bean plants. Roman et al. (2007) studied germination of $O$. foetida seeds collected on chickpea and faba bean in the presence of both host roots and showed that germination percentages varied depending on the host used both for collecting or evaluating the trait. Maximum germination percentages were obtained with seeds collected on faba bean and minimum percentages with seeds collected on chickpea. Chickpea induced a higher percentage of germinated seeds than faba bean, regardless of the host from which the seeds were collected. These authors explain these data by the possible difference in the amount and/or type of stimulatory/ inhibitory substances exudated by the two host, and also by the difference in the receptors for the germination stimulants between both orobanche species.

Nonsignificant differences in $O$. foetida germination were observed between the six tested genotypes. These results indicated that orobanche seeds germination rate cannot be taken as an indicator of resistance/tolerance of chickpea to $O$. foetida. In contrast, Rubiales et al. (2003b) indicated that for the pathosystem chickpea/O. crenata, reduced orobanche seed germination percentage appears to be a key in the resistance mechanism in some Cicer accessions. Most studies on legume resistance to broomrape concluded that resistance is correlated with low stimulatory activity by root exudates of the host plant (Rubiales et al., 2003b; 2004; 2006; Abbes et al., 2007b; 2010). In contrast, several other studies showed that resistant accessions presented the same orobanche seeds germination percentage or even greater than that observed on a sensitive accession (Ter Borg et al., 1994). Thus, advanced biochemical study on the amount and type of germination stimulants in chickpea root exudates is required. The germination percentage decrease observed for the resistant genotypes/accessions could be related to the production of inhibitors rather than a decrease of root stimulants production, or a combination of both (Whitney and Carstein, 1981). Most reports available on this topic suggest that the eliciting activity of root exudates depends on the respective concentrations of germination stimulants and germination inhibitors in root exudates (Whitney, 1978; Serghini et al., 2001; El-Halmouch et al., 2006). Thus, germination inhibitors have been identified in the root exudates of fenugreek (Evidente et al., 2007). Also, phytoalexins have been reported as inhibitors of germination of broomrape (Serghini et al., 2001). The six chickpea genotypes induced radical browning of germinated seeds and then death of the parasite. The observed necrosis is very low and seems to not be involved in the resistance/tolerance to O.foetida.

In this experiment, the maximum tubercle attachments (four tubercles per plant) were recorded for the genotypes G3, G5, and G6 confirming the relative susceptibility of the first two genotypes (G3 and G5) to $O$. foetida as mentioned in field and pots trials. Both genotypes G2 and G4 showed a low infection level (two tubercles per plant) confirming the results obtained under field conditions and in pot experiments. In addition to the reduced number of tubercles, the genotype G2 was also characterized by a slow parasite development once attached to its roots expressed by the very low percentage of tubercles reaching the stage 4 , and by the delay in the tubercle stage 4 development on this genotype. Contrary and compared to the genotype G2, G4 that also showed a high resistance/tolerance level under field conditions, in pots and petri dishes experiments presented a faster tubercle development. In addition, the high number of observed attachments on G5 was associated with a very high parasite growth rate. Thus the percentage of tubercles reaching Stage 4 by the total number of fixed tubercles is high. Tubercles stage 4 appears very early compared to the genotypes identified as tolerant (Figure 4).

The decrease of the attached tubercles number and their low speed of development once fixed on the roots of the resistant genotypes have been explained by various resistance mechanisms. Labrousse et al. (2001) showed that 
the resistance of sunflower to $O$. cumana was related to the presence of an encapsulating layer between the parasite and the root tissue of the host. Similarly, an increase in production of phytoalexins (maackian and medicarpin) has been reported in resistant chickpea (Wegmann et al., 1991), which may play a role in early blocking of the broomrape infection. On the other hand, Joel et al. (1996) suggest that phytoalexins could contribute to a delay rather than blocking of parasite development because their synthesis is relatively slow compared with the rapid intrusion of haustoria. Necrosis and/or development of protective layers that block the development or intrusion of haustorium within the host tissue has been reported on vetch parasitized by P. aegyptiaca (Goldwasser et al., 1997) and chickpea infected by $O$. crenata (Rubiales et al., 2003b). Furthermore, Rubiales et al. (2003b) reported that in addition to a low stimulation of the parasite seeds, browning at the level of contact area between the host plant root and the parasite is one of the resistance mechanisms that allow the host to prevent or reduce the installation of the parasite on its root system. Hemissi et al. (2013) reported that inoculation of chickpea seeds by certain strains of Rhyzobium leguminosarum causes the induction of resistance to $O$. foetida. The same observation has also been described in the pathosystem faba bean/O. foetida (Bouraoui et al., 2012) and the pathosystem pea/O. crenata (Mabrouk et al., 2007). The infection rate reduction was explained by the decrease of the parasite seeds germination stimulation and/or by the presence of necrosis before or after tubercle attachment.

\section{CONCLUSIONS}

Field trials, pot, and petri dishes experiments demonstrated that partial resistance to Orobanche foetida is present in chickpea. The identified resistance was not related to low induction of parasite seed germination but essentially to low number of attached tubercles per host plant and a low development of established parasite tubercles. Future advanced studies on the relationships between the resistant genotypes used in this study such the G2 genotype and $O$. foetida could be useful in order to elucidate the different mechanisms implied in this resistance. The identification of these resistance mechanisms could be of great interest in order to successfully select chickpea resistant genotypes and therefore predict the danger that can cause this parasitic plant, which is reported in Tunisia as a very virulent and aggressive especially on faba bean.

\section{REFERENCES}

Abbes, Z., M. Kharrat, and W. Chaibi. 2008. Seed germination and tubercle development of Orobanche foetida and Orobanche crenata in presence of different plant species. Tunisian Journal of Plant Protection 3:101-109.

Abbes, Z., M. Kharrat, P. Delavault, P. Simier, and W. Chaïbi. 2007a. Field evaluation of the resistance of some faba bean (Vicia faba L.) genotypes to the parasitic weed Orobanche foetida Poiret. Crop Protection 26:1777-1784.
Abbes, Z., M. Kharrat, J.B. Pouvreau, P. Delavault, W. Chaïbi, and P. Simier. 2010. The dynamics of faba bean (Vicia faba L.) parasitism by Orobanche foetida. Phytopathologia Mediterranea 49:239-248.

Abbes, Z., M. Kharrat, P. Simier, and W. Chaïbi. 2007b. Characterization of resistance to crenate broomrape (Orobanche crenata) in a new small-seeded line of Tunisian faba beans. Phytoprotection 88:83-92.

Abbes, Z., F. Sellami, M. Amri, and M. Kharrat. 2011. Variation in the resistance of some faba bean genotypes to Orobanche crenata. Pakistan Journal of Botany 43:2017-2021.

Amri, M., M. Bouhadida, M.H. Halila, and M. Kharrat. 2014. Chickpea cropping and breeding program: An overview on the Tunisian situation. Legume Perspectives. The Journal of the International Legume Society 3:58-61.

Amri, M., O. Mlayeh, and M. Kharrat. 2009. Pathogenicity of different broomrape populations on five host plant species. In Proceedings of $10^{\text {th }}$ World Congress of Parasitic Plants, Kusadasi. 8-12 June 2009. International Parasitic Plant Society (IPPS), Kusadasi, Turkey.

Arnon, D.I. 1949. Copper enzymes in isolated chloroplasts. Polyphenol-oxidase in Beta vulgaris. Plant Physiology 24:1-15.

Borg, S.J. (ed.) 1986. Effects of environmental factors on Orobanche-host relationships: A review and some recent results. p. 57-69. In Biology and control of orobanche: Proceedings of a Workshop, Wageningen. 13-17 January 1986. LH/VPO, Wageningen, The Netherlands.

Bouraoui, M., Z. Abbes, N. Abdi, I. Hmissi, and B. Sifi. 2012. Evaluation of efficient Rhizobium isolates as biological control agents of Orobanche foetida Poir. parasitizing Vicia faba L. minor in Tunisia. Bulgarian Journal of Agricultural Science 18:557-564.

El-Halmouch, Y., H. Benharrat, and P. Thalouarn. 2006. Effect of root exudates from different tomato genotypes on broomrape $(O$. aegyptiaca) seed germination and tubercle development. Crop Protection 25:501-507.

Evidente, A., M. Fernandez-Aparicio, A. Andolfi, D. Rubiales, and A. Motta. 2007. Trigoxazonane, a monosubstituted trioxazonane by Trigonella foenum-graecum root exudate, inhibiting agent of Orobanche crenata seed germination. Phytochemistry 68: 2487-2492.

Garcia-Torres, L., F. Lopez-Granados, M. Jurado-Exposito, and J. Diaz-Sanchez. 1999. Chemical control of Orobanche in legumes: achievements and constraints. p. 239-250. In Kroschel, J., M. Abderabihi and H. Betz (eds.) Workshop on Joint Action to Control Orobanche in the WANA-region: Experiences from Morocco. Rabat, Morocco. 30 March-2 April 1998. Margraf Verlag, Weikersheim, Germany.

Garcia-Torres, L., F. Lopez-Granados, and L. Savedra. 1991. New herbicides for broomrape (Orobanche crenata) control in faba bean (Vicia faba).p. 200-208. In Proceedings of the International Workshop on Orobanche Research Eberhard-Karls Universität, Tubingen, Germany.

Goldwasser, Y., Y. Kleifeld, D. Plakhine, and B. Rubin. 1997. Variation in vetch (Vicia spp.) response to Orobanche aegyptiaca. Weed Science 45:756-762.

Halila, I., J. Rubio, T. Millán, J. Gil, M. Kharrat, and M. Marrakchi. 2010. Resistance in chickpea (Cicer arietinum) to Fusarium wilt race '0'. Plant Breeding 129:563-566.

Hemissi, I., Y. Mabrouk, N. Abdi, M. Bouraoui, M. Saidi, and B. Sifi. 2013. Growth promotion and protection against Orobanche foetida of chickpea (Cicer aerietinum) by two Rhizobium strains under greenhouse conditions. African Journal of Biotechnology 12:1371-1377. 
Joel, D.M., J. Losner-Goshen, J. Hershenhorn, Y. Goldwasser, and M. Assayag. 1996. The haustorium and its development in compatible and resistance hosts. p. 531-541. In Moreno, M.T., J.I. Cubero, D. Berner, D.M. Joel, L.J. Musselman, and C. Parker (eds.) Advances in Parasitic Plant Research, Junta Andalucia, Sevilla, Spain.

Labrousse, P., M.C. Arnaud, H. Serieys, A. Berville, and P. Thalouarn. 2001. Several mechanisms are involved in resistance of Helianthus to Orobanche cumana Wallr. Annals of Botany 88:859-868.

Linke, K.H., and M.C. Saxina. 1992. Orobanche control. Legume Program Annual Report. p. 259-265.

Linke, K.H., K.B. Singh, and M.C. Saxena. 1991. Screening technique or resistance to Orobanche crenata Forks. In chickpea. International Chickpea Newsletter 24:32-34.

Mabrouk, Y., and O. Belhadj. 2012. Integrated pest management in chickpea. p. 19-38. In Bandani A.R. (ed.) New perspective in plant protection. Available at http://cdn.intechopen.com/ pdfs/35405/InTech-Integrated_pest_management_in_chickpea. pdf (accessed July 2015)

Mabrouk, Y., L. Zourgui, B. Sifi, P. Delavault, P. Simier, and O. Belhadj. 2007. Some compatible Rhizobium leguminosarum strains in peas decrease infections when parasitised by Orobanche crenata. Weed Research 47:44-53.

Mauromicale, G., A. Lo Monaco, and A.M.G. Longo. 2008. Effect of branched broomrape (Orobanche ramosa) infection on the growth and photosynthesis of tomato. Weed Science 56:574-581.

Millán, T., E. Madrid, J.I. Cubero, M. Amri, P. Castro, and J. Rubio. 2015. Chickpea. p. 88-109. In De Ron, A. (ed.) Grain legumes. Handbook of plant breeding 10. Springer Science+Business Media New York 2015. doi:10.1007/978-1-4939-2797-5_3.

Roman, B., Z. Satovic, C. Alfaro, M.T. Moreno, M. Kharrat, A. Perez-de-Luque, et al. 2007. Host differentiation in Orobanche foetida Poir. Flora 202:201-208.

Rubiales, D., C. Alcantara, A. Perez-de-Luque, J. Gil, and J.C. Sillero. 2003a. Infection of chickpea (Cicer arietinum) by crenate broomrape (Orobanche crenata) as influenced by sowing date and weather conditions. Agronomie 23:359-362.

Rubiales, D., C. Alcantara, and J.C. Sillero. 2004. Variation in resistance to Orobanche crenata in species of Cicer. Weed Research 44:27-32.
Rubiales, D., A. Perez-de-Luque, M. Fernandez-Aparicio, J.C. Sillero, B. Roman, M. Kharrat, et al. 2006. Screening techniques and sources of resistance against parasitic weeds in grain legumes. Euphytica 147:187-199.

Rubiales, D., A. Perez-de-Luque, D.M. Joel, C. Alcantara, and J.C. Sillero. 2003b. Characterisation of resistance in chickpea to crenate broomrape (Orobanche crenata). Weed Science 51:702-707.

Serghini, K., A. Perez-de-Luque, M. Castejon-Munoz, L. GarciaTorres, and J.V. Jorrin. 2001. Sunflower (Helianthus annuus L.) response to broomrape (Orobanche cernua Loefl.) parasitism: induced synthesis and excretion of 7-hydroxylated simple coumarins. Journal of Experimental Botany 52:2227-2234.

Sillero, J.C., J.I. Cubero, M. Fernandez-Aparicio, and D. Rubiales. 2005. Search for resistance to crenate broomrape (Orobanche crenata) in Lathyrus. Lathyrus Lathyrism Newsletter 4:7-9.

Soliman, M.M., A.M. Soheir, G.A. Nagat, M.A., Raslan, and M. Fergany. 2012. Screening chickpea (Cicer arietinum) for resistance to crenate broomrape (Orobanche crenata Forsk.) in Middle Egypt. Advances in Environmental Biology 6:2714-2719

Trabelsi, I., Z. Abbes, M. Amri, and M. Kharrat. 2015. Performance of faba bean genotypes with Orobanche foetida Poir. and Orobanche crenata Forsk. infestation in Tunisia. Chilean Journal of Agricultural Research 75:27-34.

Ter Borg, S.J., A. Willemsen, S.A. Khalil, H.A. Saber, J.A.C. Verkleij, and A.H. Pieterse. 1994. Field study of the interaction between Orobanche crenata Forsk. and some lines of Vicia faba. Crop Protection 13:611-616.

Wegmann, K., E. von Elert, H.J. Harloff, and M. Stadler. 1991. Tolerance and resistance to Orobanche. p. 318-321. In Wegmann, K., and L.J. Musselman (eds.) Progress in Orobanche research. Proceedings of a Workshop on Orobanche, Eberhard-KarlsUniversitat, Tubingen, Germany.

Whitney, P.J. 1978. Broomrape (orobanche) seed germination inhibitors from plant roots. Annals of Applied Biology 9:475-478.

Whitney, P.J., and C. Carstein. 1981. Chemotropic response of broomrape radicles to host roots exudates. Annals of Botany 48:919-921. 